\title{
The Feast and the Icon of the Holy Trinity - Manifestation of the Providence in History
}

\section{Dragoș Ioan ȘUȘMAN*}

Abstract: The present study makes an excursion in the history of the Slavic Church from the $14^{\text {th }}$ century. It tries to emphasize the impact that St. Sergius of Radonezh had over the development of the Russian people. The legacy left by this saint - the model of the harmony inside the Holy Trinity - gathered around his monastery - Holy Trinity in Sergiev Posad - the kernel of an entire civilization. One of his followers was St. Andrew Rublev, the author of the well known icon of the Holy Trinity, which has become a standard in the Orthodox world. The Romanian people also benefited from St. Sergius influence, overcoming the hardships of history due to our capacity to assimilate the model of the Trinitarian unity.

Keywords: history, icon, unity, genesis, holiness

According to the Byzantine tradition, the day after a major holiday is dedicated to the persons who had a contribution to the specific event. The Pentecost celebrates the descent of the Holy Spirit over the 12 Apostles, so the following day, according to the Synaxarium from the Pentecostarion, is dedicated to the Holy

* PhD, Deacon, Assistant Professor, Faculty of Orthodox Theology at "1 Decembrie 1918" University, Alba Iulia. Last work: Monografia muzicii culte românești din zona Sebeș-Alba, Alba Iulia, Altip Publishing House, 2015. Contact: susmandragosioan@yahoo.com. 
Spirit ${ }^{1}$. But, the Romanian Orthodox Church has given this day a different signification: on this particular day, Romanians celebrate the Holy Trinity.

Liturgists' opinions regarding the origin of this feast differ. On one hand Prof. Ene Braniste considers this feast to be of "Catholic influence (the Catholic Church celebrates the Holy Trinity on the first Sunday after Pentecost)"2.

On the other hand, many other liturgists think that the origins of this feast lie in the Slavic tradition, being connected to a great saint- Sergius of Radonezh (1313-1392) ${ }^{3}$. This proves that, although Orthodoxy is of Byzantine descent, it does not end with Byzantium.

The era of St. Sergius -in which Russia emerged as a state, coagulating around Moscow- coincides with one of the greatest cultural catastrophes in history: the fall of the Byzantine Empire. St Sergius lived about 60 years before the final fall of Constantinople. Still, to quote an old saying: "before the candle dies out, its flame becomes brighter". Medieval Byzantium knew one last important development in the $14^{\text {th }}$ century, the so-called $3^{\text {rd }}$ Renaissance of Byzantium, under the rule of the Palaiologos Dynasty, when all the spiritual forces of the Eastern Roman Empire were awakened again: speculative philosophy, poetry and plastic arts.

${ }^{1}$,This day, we are celebrating the Holy, Life giving and Almighty Spirit, Who is one from the Trinity, God...”. Penticostar, București, E.I.B.M.B.O.R, 1973, p. 373.

2 Ene BRANIȘTE, Liturgica generală, Ed. a III-a, Galați, Edit. Episcopiei Dunării de Jos, 2002, p. 149.

${ }^{3}$ The dating was taken from the work of Paul EvDochIMov, Arta icoanei - $o$ teologie a frumuseții (The art of Icons- a theology of beauty), București, Edit. Meridiane, 1993, p. 208. The year of his death is unanimously agreed upon, but his birth year is uncertain. 
Old Russia lights its candle directly from the sacred fire of Byzantium. All the things that were found dispersed in Byzantium, are gathered once again and revitalized in the vigorous heart of a young people, due to the shining personality of St. Sergius of Radonezh ${ }^{4}$

According to the "Life of St. Sergius", his parents, Kiril and Maria, vowed to consecrate him to God, while he was still in his mother's womb (in case he was a boy). The baby was born on the $3^{\text {rd }}$ of May 1313 and was baptized Bartholomew, honoring the saint celebrated that day.

St Sergius himself proved to be attracted towards a holy life even before he was born. While his pregnant mother was attending the Holy Liturgy, the people heard the baby crying with excitement. The voice of the baby was miraculously heard three times: before the reading of the Gospel, during the Cherubim hymn and at the words : "Holy Things for the Holy". 5

St Sergius of Radonezh did not leave any theological treaty, but he consecrated his entire life to the Holy Trinity. Object of his eternal contemplation, this divine mystery poured into his soul and transformed him into a living symbol of peace, radiating for all to see. He dedicated his church to the Trinity and tried to project the image of its unity in the heart of the people around him, even influencing the political life of his era. He summoned the whole Russia around his church and around the Name of God, so, "through the contemplation of the Trinity, people might defeat the heartbreaking hatred of the world". ${ }^{6}$

${ }^{4}$ Pavel FloRENSKI, Iconostasul, trad. și cronologie Boris Buzilă, București, Edit. Anastasia, 1994, pp. 56-57.

5 *** http://www.crestinortodox.ro/sfinti/sfantul-serghie-radonej-142064.html (21.04.2017)

${ }^{6}$ Paul Evdochimov, op. cit.,, p. 208. St. Sergius is considered the key that opens the access to the heart of the Russian people: , In order to understand Russia, you must understand the Lavra, in order to understand the Lavra, 
It is no coincidence that the teaching about the Holy Trinity reached its fulfillment in Byzantium during the saint's life. St Gregory Palamas defined his theology of the uncreated energies in the 1330s, during the Hesychast controversy. These problems preoccupied St. Sergius as well, and, in order to learn about these new teachings, he sent one of his trusted disciples to Constantinople.

"After uttering this last word, Byzantium fulfilled its historic mission... it was the dawn of a new era- the era in which the word would come to life on a cultural level and the cultural mission of Byzantium would be transferred to a new people. This new people had already accepted its destiny, as a receptacle of the divine knowledge, and was able to embody this heavenly archetype. The powers of Byzantium were decreasing, while in the Russian swamps, a new state was born. The symbol of its new cultural mission was "the revelation of the Trinity". ${ }^{7}$

The Trinity is called "life giving"- the origin and the spring of life, also "in one essence undivided" because unity in love means life, while enmity, discord and division destroy, smother and lead to death. The death bringing discord is overruled by the "life giving unity that is continuously fulfilled through the spiritual work of love and mutual understanding. According to the intention of the founder, "the church of the Holy Trinity is the prototype of the gathering of the Russians in spiritual union and brotherly love." 8

St. Sergius was famous for his hospitable nature. Not only did he often mention hospitality in his sermons, but he also embodied this virtue in his life: bestowing all sorts of gifts on his

you must come closer carefully to its founder St Sergios, the wonderful abbot, aknowledged as a saint by his contemporaries even before his death" . Cf. Pavel FlORENSKI, op. cit., p. 56.

${ }^{7}$ Pavel FLORENSKI, op. cit., p. 60.

${ }^{8}$ Ibidem, p. 62. 
followers: from a slice of bread to miraculous cures for the body and soul. He would even make small toys for children, in order to help them realize the beauty of faith. His goal was to help the people lift their spirit in contemplation from the church of the Holy Trinity to the archetype of the divine unity. Due to this fact, the building of more and more churches dedicated to the Trinity, is undoubtedly linked to the name of St Sergius. Often these churches would also have a small altar dedicated to him. ${ }^{9}$

The house of the life giving Trinity was and will always be recognized as the heart of Russia, and the person who built it, St Sergius "the defender and most holy helper of our Russian Empire", as he was named in 1689 by the Tsars: Jan Peter Alekseevici 10 "the guardian angel of Russia"11

According to some, the wooden church that was built by St Sergius was the first ever dedicated to the Holy Trinity. ${ }^{12}$ Old historiographies mention the existence (between the $4^{\text {th }}$ and the 9th century) of less than four churches dedicated to the Holy Trinity in the Eastern world and two in the West. Even if this information were true, the practice of choosing such a spiritual patron was not widely spread. In fact, those churches didn't keep

${ }^{9}$ Ibidem, p. 63.

${ }^{10}$ In the year 1689, the tzarevici Petru Alekseevici - who would later become Peter the Great- took refuge in the monastery of the Holy Trinity. At the time, it was rumored that his sister, the regent Sofia, had sent troups of streletz to capture him and and remove him from the throne. The troups did arrive at the monastery, but instead of arresting the prince, they helped him seize the thone. The event was recorded as a mirracle performed by $\mathrm{St}$ Sergius. Ibidem, p. 248, note 9.

${ }^{11}$ Ibidem, p. 55. St. Sergios was declared „Defender of Russia” in the year 1422. Cf. http://www.crestinortodox.ro/biserica-lume/lavra-sfantuluiserghie-radonej-sfanta-treime-67687.html (22.04.2017)

12 The Lavra is situated in the town of Sergiyev Posad (known as Zagorsk during the soviet era), about $80 \mathrm{~km}$ north east to Moskow. 
this name for long. In later centuries no such eastern churches were found. ${ }^{13}$

It's possible that some old wooden churches caught fire being replaced by new ones which were dedicated to the Holy Trinity $^{14}$. There are three important aspects that we must consider: frequent. ${ }^{15}$

1. in the old days "re-baptising churches" was quite

2. some chronicles attest several different names for the same church ${ }^{16}$.

3. The progress of the theological and philosophical awareness of the Eastern Church during the $14^{\text {th }}$ century made it possible to focus on the Trinitarian theme as the central topic of faith.

Consequently, many churches were built under the patronage of the Trinity. Trinitarian iconography flourished, a new Trinitarian holiday cycle was considered and a new liturgical poetry emerged. It is unlikely that Churches dedicated to the Holy Trinity were built prior to this date, and even if some were, we can safely "consider them mere historical accidents rather than common practice. Or they could be premonitions of a phenomenon that only emerged in the $14^{\text {th }}$ century". ${ }^{17}$

When a church was dedicated to the Holy Trinity, the icon of the patrons should also be present, since it expressed the

${ }^{13}$ Pavel FLORENSKI, op. cit., p. 61.

${ }^{14}$ In this case, the patronage could have been retroactively applied to the old church.

${ }^{15}$ For example the Church of the Holy Spirit from the St Sergois Monastery, had previously been dedicated to the Holy Trinity. Cf. Pavel FLORENSKI, op. cit., p. 61.

${ }^{16}$ For example, the Church of the Holy Trinity from Krakaw is also called „Mother of God”. Ibidem.

${ }^{17}$ Ibidem, p. 62. 
essence of the church itself. This is why 17 years after St Sergius' death, his disciple Nikon ${ }^{18}$ asked the well known iconographer Andrew Rublev to paint the iconostasis of the church.

According to contemporary sources, during the days of feast, when Andrew and brother Daniel ${ }^{19}$ were not working, they used to "stand before the holy icons, contemplating them and lifting their spirit and their mind towards the immaterial divine light..."20. Andrew Rublev knew how to express this divine light in his celebrated icon of the Trinity. ${ }^{21}$ This heavenly light was exactly what Russia needed in that era, which was dominated by divisions, squabbles between brothers and suffocated by Tartar raids. $^{22}$ In such harsh times, when the peril of Russia seemed

${ }^{18}$ He rebuilt the church of the Holy Trinity in white stone above the resting place of the saint, after the tartars had set fire to the old wooden church in 1408. Cf. http://hristos-imparatul-slavei.blogspot.ro/2011/11/17noiembriepomenirea-sfantului-cuvios.html ( 22.04.2017). Other sources state that the first stone church was built by a group of Serbian monks who seeked refuge in the monastery after the Battle of Kosovo. In 1422 the relics of St Sergious were placed in this church. Cf. http://www.crestinortodox.ro/biserica-lume/lavra-sfantului-serghieradonej-sfanta-treime-67687.html (22.04.2017)

19 The monk's full name was Daniel Tchiorny. In the year 1408, the two painted the Dormition of the Theotokos Cathedral in Vladimir, and between 1425 and 1427 the church of the Holy Trinity of the St Sergius monastery. Cf. La Galerie Trétiakov Moscou - Peintures russes et soviétiques, Léningrad, Editions d’Art Aurora, 1987.

${ }^{20}$ Paul EvDochimov, op. cit., p. 209.

${ }^{21}$ This way, the uncreated light of the Holy Trinity, experienced and defined theologically by Sf. Gregory Palamas, became present in iconography. After almost 150 years, ,the Synod of the 100 chapters", raised the icon painted in 1425 to the rank of ,iconographical model of every representation of the Holy Trinity" . Cf. Ibidem.

22 The role played by St. Sergios in the formation of the Russian State and in its liberation from the Tartar heel is unanimously accepted by both ecclesiastical and secular russian istoriography, according to Pavel FLORENSKI, op. cit., p. 248, nota 10. 
imminent, the profound spiritual eye was opened towards the divine (...) unlimited, untangled and unshaken Light. The hatred that dominated the earthly world was overwhelmed by reciprocal love pouring from above in a blissful whisper, an eternal unity with the heavenly spheres.

The famous icon painted by Andrew Rublev is an important step in the evolution of the iconographic composition called "Abraham's Philoxenia". The history of this composition is very long. According to Julius Africanus, in the year 314 AD near the Oak in Mamvri there was a painting that showed Abraham welcoming the three Divine Pilgrims. Similar paintings from the $5^{\text {th }}$ and $6^{\text {th }}$ centuries can be found on the walls of Santa Maria Maggiore in Rome and San Vitale in Ravenna. Since then, this subject has been frequently depicted. ${ }^{23}$

The illuminated manuscript written by the monk Epiphanes $^{24}$ shows that since the second half of St Sergios' life, one could find an icon of the Holy Trinity in the saint's private cell. This icon will be replaced by his disciple Nikon with a representation made by Andrew Rublev. This gesture did not undermine the Saint's authority, but rather it affirmed it once again, since, as an artist, Andrew Rublev developed his style being nurtured by St Sergios' theology. He was not an independent creator, but rather a genial implementer of the creative and compositional project initiated by St. Sergius. This is

${ }^{23}$ Ibidem, p. 64.

${ }^{24}$ The monk Epiphannes began this monastic life in the second half of the 14th century in the city of Rostov, in the Monastery of St. Gregory the THeologian. After a pilgrimage to the Holy Land, he became the disciple of St Sergios of Radonedz, remaining in the Monastery of the Holy Trinity for the rest of his life. In 1418 he started writing the life of St. Sergios finalising the work within the same year. He passed away around the year 1420. Cf. http://traducerisioriged.blogspot.ro/2009/08/sfantul-serghie-deradonej-teologul.html (22.04.2017) 
why St Sergius of Radonezh should be honoured as the true creator of the masterpiece that took shape under the skillful hand of St. Andrew Rublev. ${ }^{25}$

The greatest liturgical mutation in which the particularities of the Russian spirit were to be found, is also connected with St. Sergius: the Feast of the Holy Trinity. Bizantium did not have this feast, the same way as it did not have churches or icons dedicated to the Holy Trinity. The last word of Byzantium in terms of dogma became the starting point for the first creative forces of the Russian culture. Until the $14^{\text {th }}$ century, the feast of Pentecost that occupied the place on which Russians put the feast of the Holy Trinity, had more a historical signification and not a really ontological one. ${ }^{26}$

Maybe the feast of the Holy Trinity appeared for the first time when the Russian people decided to celebrate the beautiful icon of Andrew Rublev in the Cathedral of the Holy Trinity from the St. Sergius Lavra. In the same way the Resurrection service first preformed in the Church of the Holy Sepulcre in Jerusalem, became later the model for all the Resurrection Services in the Orthodox world, being inserted in the Tipikon. Also the feast of the Elevation of the Cross- at first a unique event, was later

${ }^{25}$ Pavel FLORENSKI, op. cit., p. 65.

${ }^{26}$ The adoration of he Holy Trinity seems more the object of the service from the Sunday of Pentecost (see the stichera for „Glory...” written by Leon the Despot after "O Lord, I have cried out to You; hear me;..." from the Vespers of the Pentecost: „Come all peoples to kneel before God in three Persons adored..."). This is why in the Russian iconographic art, the feast of the Pentecost is usually represented by the three angels from „Abraham's Philoxenia” (as it was depicted by Andre Rublev). In the latest calendars of the Russian Orthodox Church the Saturday before the Pentecost is called "Saturday of $t$ he Trinity” (Trioțkaia), and the Sunday of Pentecost is again indicated as „The Day of the Holy Trinity” (День Святой Троицы- Den Sviatâi Troițî). Cf. Pr. Prof. dr. Ene BRANIșTE, op. cit., pp. 149-150. 
inserted in Tipikons and spread throughout the world. It is possible that this feast had the same development: the celebration of one icon and one church became important and spread outside the Russian borders.

"A thing which is reflected in a thousand mirrors remains the same fundamental reality for those thousand mirrors- it is the real center in all of them. So, the first depiction of the spiritual archetype that determined the essence of Russia- the archetype of the Trinity as a cultural idea- remains a unique historical, artistic and metaphysic phenomenon, that cannot be compared to the copies that emerged after the phenomenon spread. The most beautiful Russian architectural edifice, the Cathedral of the Holy Trinity $^{27} ;[\ldots]$ the most beautiful work of the Russian iconography _ Rublev's icon [...] and the whole service of the Holy Trinity feast are important not only because they are beautiful masterpieces, but also due to their profound artistic truth, a perfect identification between the spiritual archetype of Russia and it's artistic depiction" 28 .

In the old manuscripts St Sergius is called "the leader and teacher of all the monasteries in Russia". It is not a gratuitous nickname, since at least a quarter of these monasteries were founded by his direct disciples, colonizing the northern and northeastern Russia down to the realms of Perm and Vologda ${ }^{29}$.

${ }^{27}$ „It's a church in which you'd wish to stay forever”, as Paul of Aleppo, the archdeacon of the Antiohian Patriarch, exclaimed while he was visiting the Lavra of St. Sergios on the 11th of July 1655. Pavel FLORENSKI, op. cit., p. 53.

${ }^{28}$ Ibidem, p. 66-67.

${ }^{29}$ Ibidem, p. 68. Some sources count up to 400 monasteries founded by his disciples. See: http://www.crestinortodox.ro/biserica-lume/lavra-sfantuluiserghie-radonej-sfanta-treime-67687.html (22.04.2017). 
The Lavra of the Holy Trinity ${ }^{30}$ had a civilizing influence over Russia. St. Sergius asked the brethren to perform their duties thoroughly, but also to read with great dedication. This means that lots of scriptoriums (workshops for copying manuscripts) were needed. So, the Lavra became the center of a vast literary phenomenon producing a large number of manuscripts, many of which are kept in the Lavra's precious collection. Also, the Theological Academy of Moscow, evolved from the cultural movement of Maxim the Greek, has become the "child" of the Lavra. ${ }^{31}$

The example of St Sergios, the "theologian of the Holy Trinity" was followed by other Russian saints. Among those who were nicknamed according to the Holy Trinity, because of their faith and dedication, we can mention: St Andrew Rublev_ "the painter of the Trinity", St Paul Florenski "the martyr and confessor of the Trinity" and St. Alexander from Svir called "the prophet of the Trinity". ${ }^{32}$

The Russian people was not the only one blessed by the light and unity overflowing from the Trinitarian model. This blessing was shared to other peoples as well including Romanians.The $14^{\text {th }}$ century was vital for our history as well: by

${ }^{30}$ The Monastery of the Holy Trinity was elevated to the rank of „Lavra” in 1744 by Empress Elizabeth, the Moscow metropolitan becoming also the Archimandrite of the Lavra. *** http://www.crestinortodox.ro/bisericalume/lavra-sfantului-serghie-radonej-sfanta-treime-67687.html (22.04.2017).

31 Maxim from Grece (approx. 1475-1556)- a cleric and scolar invited to Russia by the Tsar Basili III for the translation of the divine service books. $\mathrm{He}$ also wrote orriginal books with moral- religious content. Pavel FLORENSKI, op. cit., p. 249, nota 22.

32 *** http://www.crestinortodox.ro/sfinti/sfantul-alexandru-svir-avraamnoului-testament-119953.html (22.04.2017). 
the middle of this century, the Romanian regions of Wallachia ${ }^{33}$ and Moldavia ${ }^{34}$ were formed and gained their independence. By the same time Romanian churches with the patronage of the Holy Trinity $^{35}$ started to appear. This means Romanians understood that one cannot pursue history's dangerous paths without the guiding light of the divine. The Holy Trinity watched over the emergence of the first Romanian states within the Carpathian arch. After several centuries Romanians in Transylvania would also build an orthodox Cathedral in Sibiu under the same patronage (consecrating it in 1906). We have always been three little countries wanting to be "three in one and one in three", according to the model of the Trinity.

\section{Conclusions}

Seen from a terrestrial level, historical events are nothing but a succession of facts without an evident link between them. Even if we can establish some sort of causality, their global logic is still very hard to find. In order to perceive them in unity, we need to float above the mundane level and see events through the eyes of faith. As a paradox, this perspective discovers the

${ }^{33}$ In the year 1324, during the reign of Basarab I. According to. Ovidiu V. BUȚıU, Istoria formării poporului român, Târgu-Mureș, Edit. Mureș, 2004, p. 254.

${ }^{34}$ In 1359 under prince Bogdan I. Cf. Ibidem, p. 255.

${ }^{35}$ If we mention the churches and monasteries built by Mircea the Elder (13861418): Cozia monastery, Vâlcea county, erected between 1387-1388 and the monastery of the Holy Trinity from Vișina, Gorj county. During the next few hundred years other churches and monastery with the same dedication appear. For more information on the topic, one can access the works Vasile DUMITRACHE: Mânăstirile și schiturile României pas cu pas, vol. 1 - Mitropolia Olteniei, București, Edit. Nemira, 2001 and Mânăstirile şi schiturile României pas cu pas, vol. 4 - Mitropolia Ardealului, Crișanei și Maramureșului, București, Edit. Nemira, 2002. 
grandeur of the human being, who finally sees itself not as a victim of history, but as the moving force within its lifetime. The power of man resides in his relationship with the Creator, from Whom he can receive a light that is much stronger than the darkness of ages.

St Sergius of Radonezh is an important example in this respect: a man who gave coherence and meaning not only to his people, but also to ours. Sadly, no matter how much light someone is willing to shed, he can only share it to people whose eyes can perceive that light. This is the lesson taught to us by our ancestors, who built the country we are living in on the only absolute model of unity: the Holy Trinity. It is a message that we are not allowed to forget, especially around such important jubilees as the one celebrating 100 years since the Great Unification.

If our ancestors were capable to assume and transmit the model of Trinitarian unity for over half a millennium, (between the $14^{\text {th }}$ and $20^{\text {th }}$ centuries/ as the Great Unification took place in1918)- it would be shameful for us to loose this model after just 100 years.

\section{References}

1. BRANișTE, Ene, Liturgica generală (General Liturgics), Ed. a III-a, Galaţi, Edit. Episcopiei Dunării de Jos, 2002.

2. BuțıU, Ovidiu V., Istoria formării poporului român (The History of the Formation of the Romanian People), Târgu-Mureș, Edit. Mureș, 2004.

3. Dumitrache, Vasile, Mânăstirile și schiturile României pas cu pas (The Monasteries and Sketes of Romania- Step by Step), vol. 1 - Mitropolia Olteniei, București, Edit. Nemira, 2001.

4. Idem, Mânăstirile și schiturile României pas cu pas (The Monasteries and Sketes of Romania- Step by Step), vol. 4 - 
Mitropolia Ardealului, Crișanei și Maramureșului, București, Edit. Nemira, 2002.

5. Evdochimov, Paul, Arta icoanei - o teologie a frumuseții (The Art of Icons- A Theology of Beauty) , București, Edit. Meridiane, 1993.

6. FloRENSKI, Pavel, Iconostasul (The Iconostasis), trad. și cronologie Boris Buzilă, București, Edit. Anastasia, 1994.

7. *** La Galerie Trétiakov Moscou - Peintures russes et soviétiques (The Tretiakov Gallery- Russian and Soviet Paintings), Léningrad, Editions d’Art Aurora, 1987.

8. *** Penticostar (Penticostarion), București, E.I.B.M.B.O.R, 1973

\section{Web sources:}

9. http://hristos-imparatul-slavei.blogspot.ro/2011/11/17noiembriepomenirea-sfantului-cuvios.html

10. http://traducerisioriged.blogspot.ro/2009/08/sfantul-serghie-deradonej-teologul.html

11. http://www.crestinortodox.ro/biserica-lume/lavra-sfantuluiserghie-radonej-sfanta-treime-67687.html

12. http://www.crestinortodox.ro/sfinti/sfantul-alexandru-sviravraam-noului-testament-119953.html

13. http://www.crestinortodox.ro/sfinti/sfantul-serghie-radonej$\underline{142064 . h t m l}$ 